\title{
Techno-economic Analysis (TEA) and Life Cycle Assessment (LCA) of a Low Temperature Closed-Cycle Grain Drying System
}

\author{
Mingjun $\mathrm{Ma}^{1} \&$ Kurt A. Rosentrater ${ }^{1}$ \\ ${ }^{1}$ Agricultural and Biosystems Engineering, Iowa State University, Ames, Iowa, USA \\ Correspondence: Kurt A. Rosentrater, Agricultural and Biosystems Engineering, Iowa State University, Ames, \\ Iowa, USA. Tel: 1-515-294-4019. E-mail: karosent@iastate.edu
}

Received: February 9, 2019

Accepted: March 27, 2019 Online Published: May 15, 2019

doi:10.5539/jas.v11n6p52

URL: https://doi.org/10.5539/jas.v11n6p52

\begin{abstract}
The aim of this study was to understand the environmental and economic impact of the low temperature closed-cycle grain drying system by using techno-economic analysis (TEA) and life cycle assessment (LCA). For TEA, three scales including small (60 bu/batch), medium (600 bu/batch) and large (6000 bu/batch) were chosen for analysis the total annual drying cost and unit drying cost. For LCA, the greenhouse gasses (GHG) emission was the only environmental impact that considered in this study, since the electricity was the only energy source for this drying system. The TEA result shows that the drying costs for one bushel of corn were $\$ 0.62, \$ 0.49, \$ 0.46$ for the small, medium and large scales of this drying system, respectively, and the drying cost could potentially be lower than grain elevators. The LCA results indicate that greenhouse gas emissions will increase along with the expansion of the drying system since the electricity comes from a local coal-based electricity plant, which potentially makes this drying system's greenhouse gas emissions higher than other types of drying systems. Farmers can use this method to make decisions when handling their grain.
\end{abstract}

Keywords: drying, grain, cost assessment, environmental impact

\section{Introduction}

Grains are a primary source of energy and proteins for people worldwide. The grain moisture content level is a critical factor for grain quality control and grain processing. High moisture levels inside the grain can increase the mold and fungi spoilage risks (Brooker et al., 1992). Grain drying systems reduce grain moisture content and allow for long-term grain storage, without compromising the grain quality. The key to achieving effective drying results and high drying efficiency is a well-designed drying system. From an energy usage perspective, grain drying is a very energy intensive process (Gunasekaran \& Thompson, 1986). It has been estimated that the energy use for on-farm grain drying operations is almost $50 \%$ of the overall energy used in on-farm grain processing and handling (FEA, 1974). Beedie (1995), showed that by improving drying system energy efficiency by just $1 \%$ the profits of could increase as much as $10 \%$. For this reason, many studies have been done to analyze the efficiency of different drying systems. Kenyon and Shove (1969) and Shove (1973) showed the intermittent blowing of hot air and cold air into grain could improve the overall drying efficiency. Foster (1964) introduced the dryaeration process, which first dried grain around $60{ }^{\circ} \mathrm{C}$ to approximately $2 \%$ above the target moisture content, and then the grain was transferred to a separate dryaeration bin without cooling. In the dryaeration bin, the grain was tempered 6 to 8 hours without aeration, and then was cooled slowly by using ambient air for another 8 to 12 hours (Morrison, 1979). Peterson (1979) proved this method could save up to $25 \%$ of grain drying energy.

The basic principle of LCA (Life Cycle Assessment) is a procedure to assess environmental impacts associated with a product's life from the cradle to the grave. In 1970, the Midwest Research Institute first invented this technology (Hunt \& Franklin, 1996), and the LCA procedure mostly used today was defined by ISO, including: 1) goal and scope definition, 2) inventory analysis, 3) impact assessment, and 4) interpretation.

TEA (Techno-Economic Analysis) can be defined as a systematic analysis used to assess the economic feasibility aimed to recognize opportunities and threats of projects, considering the capital, operational (variable), and fixed costs (Simba et al., 2012), and economic benefits as well. Annual operating expenses and fixed costs are critical parameters in TEA and are the basic parameters for cost estimation, process optimization, and project evaluation. 
In this study, the TEA was conducted using an MS-Excel spreadsheet to determine the overall costs of the drying system.

Although grain drying theory and methods have been well investigated for the past several decades, there are very few papers focused on explaining the environmental impacts and economic impacts for a various types of grain drying systems. The aim of this study was to analyze the environmental and economic impacts for the low temperature closed-cycle grain drying system examined by Ma and Rosentrater (2019). This study provides useful information to grain drying industry and can help farmers to make decisions when investing an on-farm grain dryers in terms of drying costs and environmental impacts.

\section{Materials and Methods}

The TEA and LCA were based on the prototype on-farm low temperature closed-cycle grain drying system that was provided by the Loebach Brothers (David R. Loebach and Joseph E. Loebach, Loebach Brothers Inc., Idaho, USA). Figure 1 shows the overall schematic of this low temperature closed-cycle drying system. The concept for this drying system was the heat pump working as a dehumidifier. The condensation and evaporation system will remove the moisture from the air that comes out of the corn container and the fan will force the mositure reduced air into the container to drying the grain. The drying performance for the baseline drying system was evaluated and reported in Ma and Rosentrater (2019).

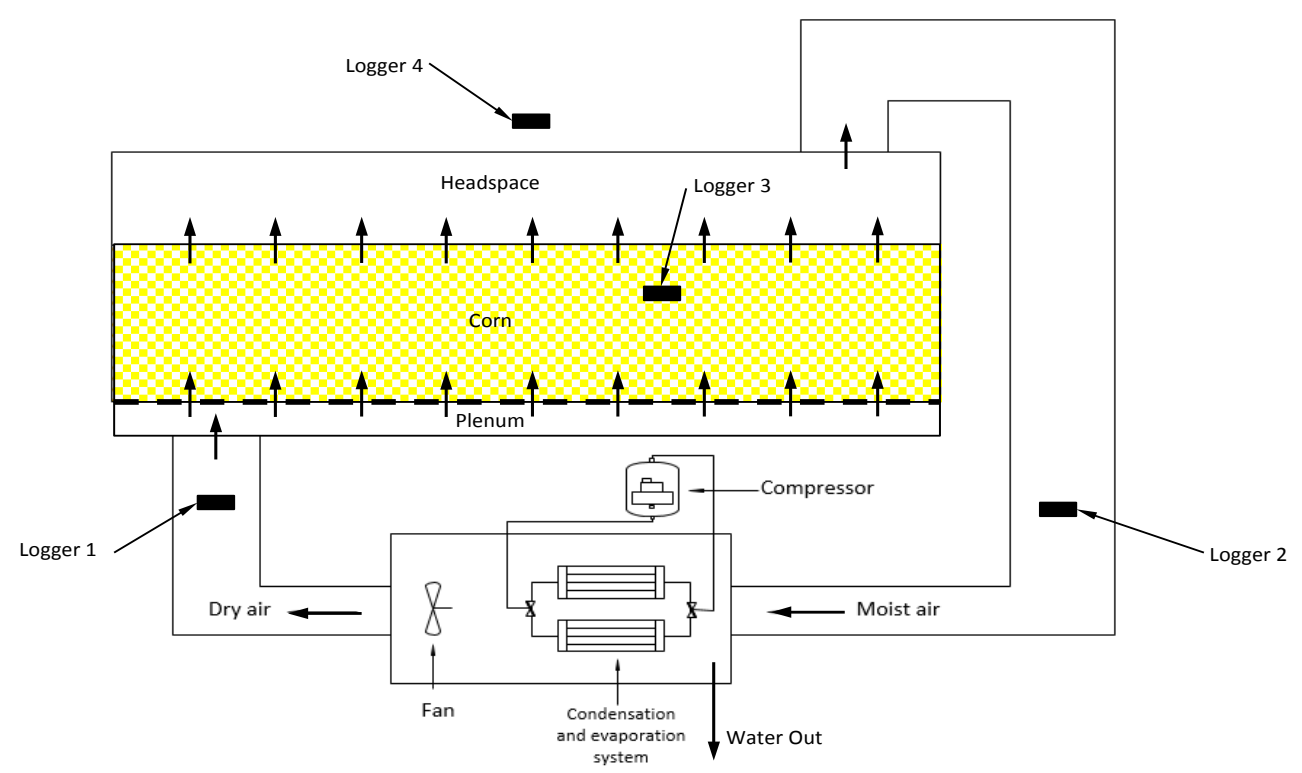

Figure 1. Overall schematic of the low temperature drying system (Ma \& Rosentrater, 2019)

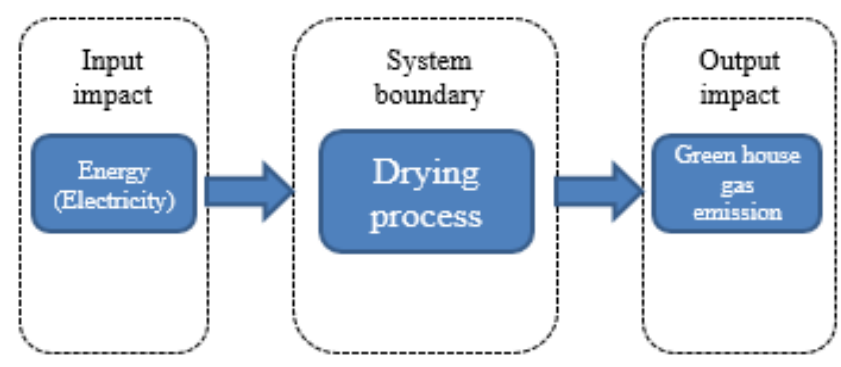

Figure 2. Flow chart of the boundaries of the grain drying system

The system boundary for LCA and TEA is shown in Figure 2. The drying system was a closed-cycle system; electricity was the only energy source that went into the drying system; the boundary for this system only includes the whole drying process. The environmental impact came from the production of the electricity from the local coal-based electricty plant. The functional unit for this TEA and LCA study was based on 1 bu of corn 
(56 lb of corn at $15.5 \%$ moisture content) dried through the drying process. Thus, this study analyzed annualized total impacts for one bushel of corn.

All the TEA and LCA for the drying system were based on three production scales, which included small (60 $\mathrm{bu} / \mathrm{batch})$, medium $(600 \mathrm{bu} / \mathrm{batch})$, and large $(6000 \mathrm{bu} / \mathrm{batch})$. A prototype baseline drying system with 60-bu/batch capacity was provided by the Loebach Brothers, and the baseline system cost and drying system component list were also provided by the Loebach Brothers. Analyzing the other scales required compiling equipment and operational information. The main assumptions for the TEA and LCA modeling are as follows:

(1) The corn initial moisture content was assumed as $28 \%$, and the corn was dried to $15 \%$ moisture content.

(2) The drying system was operated two months per year since the harvesting dates for corn in Iowa are typically from September to November (USDA, 2011).

(3) The drying operation time for each scale was assumed based on a suggestion from Shove (1970), which was for 1 ton $(12000 \mathrm{Btu} / \mathrm{h})$ of refrigeration which could dry 20 bu corn per day. For the baseline system, the capacity of the compressor was $6690 \mathrm{Btu} / \mathrm{h}$, which is 0.56 ton.

(4) The $60 \mathrm{bu} / \mathrm{batch}$ drying time was measured as 2.7 days while for $600 \mathrm{bu} / \mathrm{batch}$ and $6000 \mathrm{bu} / \mathrm{batch}$ the drying time was assumed as 6 days and 15 days, respectively.

(5) The energy consumption for drying was assumed based on our measurements (Ma \& Rosentrater, 2019) and Shove's (1970) suggestion, which was $3 \mathrm{~kW}-\mathrm{h} / \mathrm{bu}$ of corn. The baseline system energy consumption was measured as $2.83 \mathrm{~kW}-\mathrm{h} / \mathrm{bu}$ of corn.

The drying system energy consumption and consequent greenhouse gas emissions were the two main categories for our LCA study. The carbon dioxide, methane, and $\mathrm{NO}_{\mathrm{x}}$ were main factors considered for greenhouse gas emissions (GHG). Table 1 shows the GHG conversion factors for a typical coal energy plant. The carbon dioxide, methane, and $\mathrm{NO}_{\mathrm{x}}$ data were calculated by multiplying the drying systems' energy consumption by the GHG conversion factor. The global warming potential $\left(\mathrm{CO}_{2 \mathrm{eq}}\right.$-which combined the effects of $\mathrm{CO}_{2}$, methane, and $\left.\mathrm{NO}_{\mathrm{x}}\right)$ allowed comparison of the total global warming potential amongst the different drying systems. Table 2 shows the global warming potential factors for the three different GHG gases. The total global warming potential was the sum of the multiplication between GHG gases and the conversion factors.

Table 1. Air emissions for producing electricity from coal

\begin{tabular}{ll}
\hline Emission category & $\mathbf{g} / \mathbf{k W}-\mathbf{h}$ \\
\hline $\mathrm{CO}_{2}$ & 1022 \\
$\mathrm{CH}_{4}$ & 0.91 \\
$\mathrm{NO}_{\mathrm{x}}$ & 3.35 \\
\hline
\end{tabular}

Note. Based upon Spath, Mann, and Kerr (1999).

Table 2. Conversion factors for calculating global warming potential

\begin{tabular}{ll}
\hline GWP conversion factor (100 years) & mass $\mathbf{C O}_{2 \mathrm{eq}}$ \\
\hline $\mathrm{CO}_{2}$ & 1 \\
$\mathrm{CH}_{4}$ & 28 \\
$\mathrm{NO}_{\mathrm{x}}$ & 256 \\
\hline
\end{tabular}

Note. Based upon IPCC 2013-AR5 (Stocker et al., 2013).

For the TEA, the cost of each drying system component was obtained from online sources like Alibaba and PEX Supply House. The cost for drying one bushel of corn was calculated by dividing energy cost, labor cost and annual drying system cost by that bushel of corn.

The assumptions for TEA were:

(1) The corn storage bin for 600 bushels of corn was 14 feet in diameter with a height of 11 feet.

(2) The corn storage bin for 6000 bushels of corn was 24 feet in diameter with a height of 18 feet.

(3) Fan size for 600 bushels was $5 \mathrm{hp}$ while for 6000 bushel was $20 \mathrm{hp}$ (Sadaka, 2014).

(4) The life span of the drying system was assumed as 25 years. 
(5) The insurance rate was $0.5 \%$ per year and the interest rate was 7\% per year (Hellevang \& Reff, 1987).

(6) The maintenance and repair rate was $3 \%$ of total capital cost per year (Hellevang \& Reff, 1987).

(7) Labor cost for handling the corn was $0.061 \$$ per bushel of corn (Plastina \& Johanns, 2016).

(8) At the end of service life, the savage value was assumed to be $\$ 0$.

(9) The electricity rate was 10.5 cent per kW-h (EIA, 2016).

\section{Results and Discussion}

\subsection{Life Cycle Assessment (LCA)}

Based on the assumptions for unit drying energy consumption the total annual electricity usage for 60 bushels, 600 bushels, and 6000 bushels was calculated and reported in Table 3 as $3735.6 \mathrm{~kW}-\mathrm{h} / \mathrm{y}, 18,000 \mathrm{~kW}-\mathrm{h} / \mathrm{y}$ and $72000 \mathrm{~kW}-\mathrm{h} / \mathrm{y}$ respectively. The total annual electricity usage value was fit the power increase regression model very well; the R-square value was 0.999 , which was very close to 1 (Figure 3 ). The regression model was not linear was because the unit power consumption was assumed at $3 \mathrm{~kW}-\mathrm{h}$ for medium and large scale and for small scale the power consumption was $2.83 \mathrm{~kW}-\mathrm{h}$, and the total power consumption was mostly determined by the amount of the corn. Table 3 also shows $\mathrm{CO}_{2}$ emission, $\mathrm{CH}_{4}$ emission, and $\mathrm{NO}_{\mathrm{x}}$ emission data. For $\mathrm{CO}_{2}$ emission, the total annual air emission data were $3735.6 \mathrm{~kg}$ per year, $18396 \mathrm{~kg}$ per year, and $73584 \mathrm{~kg}$ per year for small, medium, and large scale respectively. For $\mathrm{CH}_{4}$ emission, the average $3.39 \mathrm{~kg}$ per year, $16.38 \mathrm{~kg}$ per year, and $65.52 \mathrm{~kg}$ per year for $60 \mathrm{bu} / \mathrm{batch}, 600 \mathrm{bu} / \mathrm{batch}$, and $6000 \mathrm{bu} / \mathrm{batch}$ respectively. The $\mathrm{NO}_{\mathrm{x}}$ emission was calculated as $12.51 \mathrm{~kg}$ per year, $30.3 \mathrm{~kg}$ per year, and $241.2 \mathrm{~kg}$ per year for small, medium, and large scale respectively. Figure 4 shows the annual total $\mathrm{CO}_{2}$ emission with various drying system capacity. The $\mathrm{CO}_{2}$ emission value fit the power increase model well and the R-square value was 0.9987 , which was same to the $\mathrm{R}$-square value for total annual electricity usage. The reason was that the emission data was calculated by multiplying the air emission conversion factor by the annual electricity usage data. From the Figure 5 and Figure 6, it was easy to observe both $\mathrm{CH}_{4}$ and $\mathrm{NO}_{\mathrm{x}}$ emission increased as the system scale increased. All the emission data fit a power model very well, with the R-square value of 0.9987 for both $\mathrm{CH}_{4}$ and $\mathrm{NO}_{\mathrm{x}}$ emission. The results were similar to $\mathrm{CO}_{2}$ emissions, and the reason was the $\mathrm{CH}_{4}$ and $\mathrm{NO}_{\mathrm{x}}$ emission data was also calculated by energy usage during the drying process.

Table 3. LCA results for closed-cycle grain drying system

\begin{tabular}{|c|c|c|c|}
\hline Capacity & $60 \mathrm{bu}$ & $600 \mathrm{bu}$ & $6000 \mathrm{bu}$ \\
\hline Environmental impact & $\begin{array}{l}\text { Total annual impact } \\
\text { (per year) }\end{array}$ & $\begin{array}{l}\text { Total annual impact } \\
\text { (per year) }\end{array}$ & $\begin{array}{l}\text { Total annual impact } \\
\text { (per year) }\end{array}$ \\
\hline Electricity usage (kW-h) & 3735.6 & 18000 & 72000 \\
\hline $\mathrm{CO}_{2}$ emission $\left(\mathrm{kg} \mathrm{CO}_{2}\right)$ & 3817.78 & 18396 & 73584 \\
\hline $\mathrm{CH}_{4}$ emission $\left(\mathrm{kg} \mathrm{CH}_{4}\right)$ & 3.39 & 16.38 & 65.52 \\
\hline $\mathrm{NO}_{\mathrm{x}}$ emission $(\mathrm{kg} \mathrm{NOx})$ & 12.51 & 60.3 & 241.2 \\
\hline Global warming potential $\left(\mathrm{kg} \mathrm{CO}_{2 \mathrm{eq}}\right)$ & 7229.25 & 34834.14 & 139336.56 \\
\hline
\end{tabular}

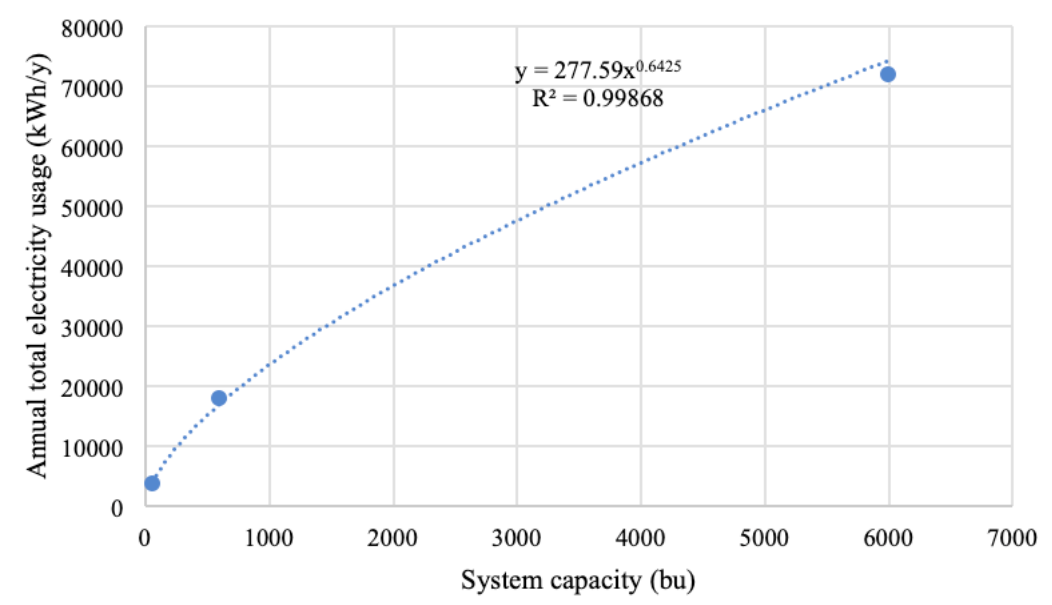

Figure 3. Annual drying electricity usage according to drying capacity 


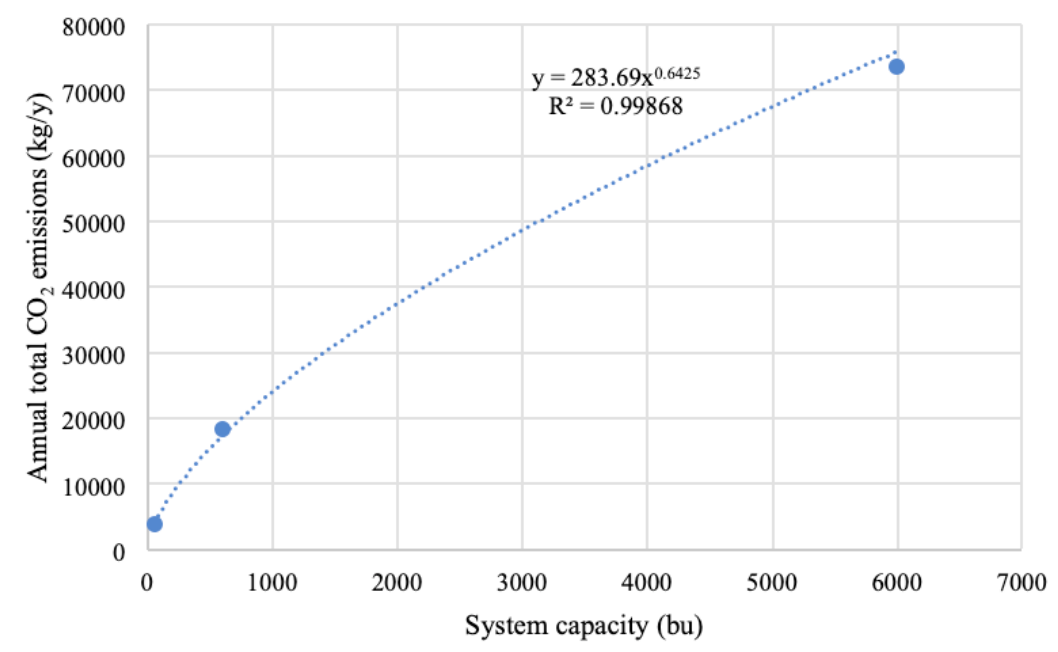

Figure 4. Annual total $\mathrm{CO}_{2}$ emissions according to drying capacity

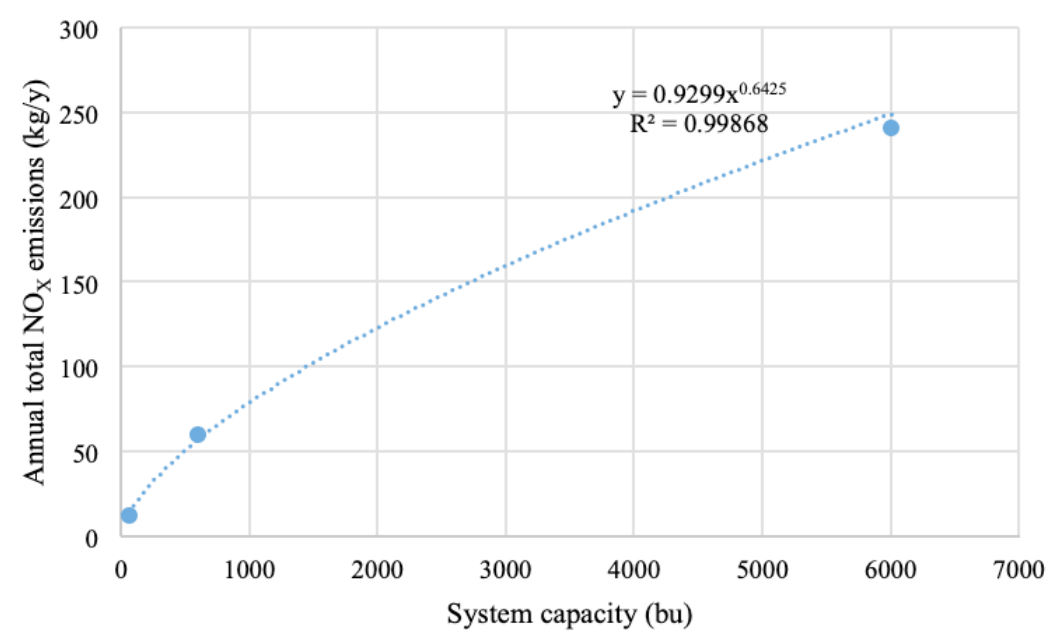

Figure 5. Annual total $\mathrm{NO}_{\mathrm{X}}$ emissions according to drying capacity

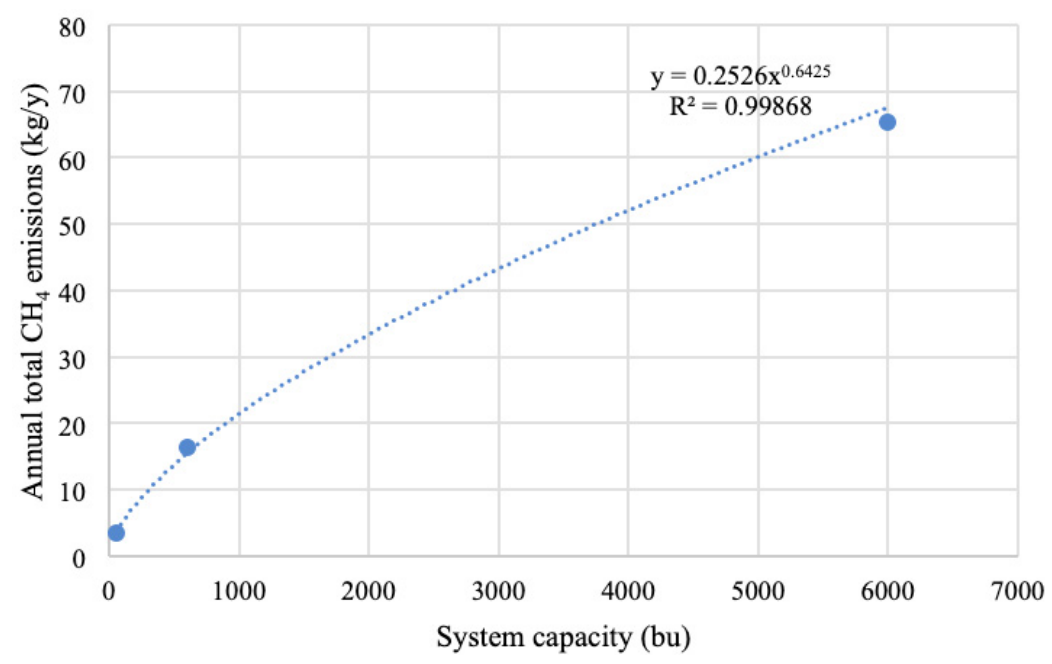

Figure 6. Annual total $\mathrm{CH}_{4}$ emissions according to drying capacity 
The global warming potential was calculated as $7229.25 \mathrm{~kg} \mathrm{CO}_{2 \mathrm{eq}}, 34834.14 \mathrm{~kg} \mathrm{CO}_{2 \mathrm{eq}}$ and $139336.56 \mathrm{~kg} \mathrm{CO}_{2 \mathrm{eq}}$ for small, medium and large scale respectively. Figure 7 shows the trend for global warming potential, and the global warming potential was increased as the drying system capacity increased. The global warming potential value fit the power model well with the R-square 0.9987 . This result was also same with annual total electricity usage results since the global warming potential results were highly related with the system electricity usage.

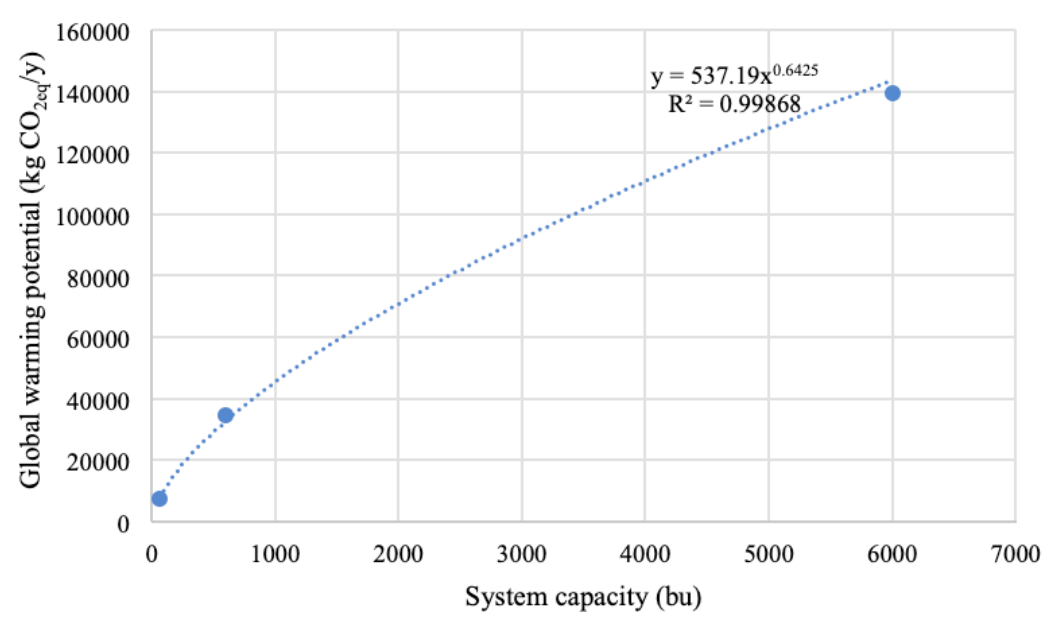

Figure 7. Annual total global warming potential according to drying capacity

Bern (1998) reported energy usage and $\mathrm{CO}_{2}$ emissions (but not $\mathrm{NO}_{\mathrm{x}}$ or methane emissions) for drying the corn in Iowa. In this report, several different drying systems and methods including off-farm drying, farm air drying, farm high temperature drying, and farm combined drying were discussed. $\mathrm{The}^{\mathrm{CO}} \mathrm{CO}_{2}$ emission data was calculated based on preserving $38.8 \times 10^{6} \mathrm{Mg}$ of corn. Comparing that $\mathrm{CO}_{2}$ emission data with the present LCA data, which were determined to be $113.86 \mathrm{~kg} \mathrm{CO} / \mathrm{Mg}$ corn, $119.14 \mathrm{~kg} \mathrm{CO}_{2} / \mathrm{Mg}$ corn, and $120.7 \mathrm{~kg} \mathrm{CO}_{2} / \mathrm{Mg}$ corn for $60 \mathrm{bu}$, $600 \mathrm{bu}$, and $6000 \mathrm{bu}$, respectively. For the present drying system, $\mathrm{CO}_{2}$ emission was only lower than the on-farm air drying method, which was $262 \mathrm{~kg} / \mathrm{Mg}$ corn. The present drying system released $41.5 \%$ to $70 \%$ more $\mathrm{CO}_{2}$ than other on-farm or off-farm drying methods. Because the electricity was the only energy source, the energy sources that produced the electricity were crucial for greenhouse gas emissions. The electricity used in this study was produced from a local coal power plant, which thus led to higher $\mathrm{CO}_{2}$ emission levels compared to the previous research. If the electricity came from a cleaner power plant, however, like wind power or hydro power, the greenhouse gas emissions could be much lower than determined in the present study.

\subsection{Techno-Economic Analysis (TEA)}

The general TEA results were reported in Tables 4, 5, 6, 7, 8 and 9. The annual economic impact for each operation capacity of this drying system was considered including capital cost and operating cost. The annual cost was $\$ 886.06$ per year, $\$ 2913.25$ per year and $\$ 10992.53$ per year for small (60 bu/batch), medium (600 $\mathrm{bu} / \mathrm{batch})$, large ( $6000 \mathrm{bu} / \mathrm{batch})$ respectively, and it was increased while the drying capacity increased. Figure 8 shows the annual drying cost results; it is evident to see that the annual drying cost could fit both linear and power model very well. The power model has R-square value 0.999 . The annual total drying cost has the similar trend with annual electricity usage results, and the R-square value for both results were also approximately the same, this was because the majority drying cost every year came from the energy cost for the drying system. 
Table 4.60 bu drying system capital costs $(\$)$

\begin{tabular}{llll}
\hline Component & Price (\$/each) & Quantity & Total Cost (\$) \\
\hline Compressor & 890.00 & 1 & 890.00 \\
Evaporators & 170.00 & 2 & 340.00 \\
Accumulator & 40.00 & 1 & 40.00 \\
Receiver & 87.00 & 1 & 87.00 \\
Expansion valves & 65.00 & 2 & 130.00 \\
Solenoid valves & 71.00 & 4 & 284.00 \\
Timer & 40.00 & 1 & 40.00 \\
Head pressure control & 100.00 & 1 & 100.00 \\
Headmaster valve & 140.00 & 1 & 140.00 \\
Blower & 160.00 & 1 & 160.00 \\
Equipment initial Costs & & & $2,211.00$ \\
Electrical wiring and controls & & & 88.44 \\
Equipment installation & & & 884.40 \\
Equipment freight & & 22.11 \\
Total equipment initial costs & & $3,205.95$ \\
Engineering and design & & 224.42 \\
\hline Total capital costs & & $3,430.37$ \\
Capital costs per year & & 294.36 \\
\hline
\end{tabular}

Table 5.60 bu drying system operating costs (\$/year)

\begin{tabular}{ll}
\hline Fixed costs & \\
\hline Insurance & 16.03 \\
Subtotal & 16.03 \\
\hline Variable costs & \\
\hline Labor cost & 80.52 \\
Electricity & 392.24 \\
Maintenance and repair & 102.91 \\
Subtotal & 575.67 \\
\hline Total costs & 886.06 \\
Drying cost/bu & 0.62 \\
\hline
\end{tabular}

Table 6. 600 bu drying system capital costs (\$)

\begin{tabular}{llll}
\hline Component & Price (\$/each) & Quantity & Total Cost (\$) \\
\hline Compressor & $1,000.00$ & 1 & $1,000.00$ \\
Evaporators & 499.00 & 2 & 998.00 \\
Accumulator & 121.00 & 1 & 121.00 \\
Receiver & 123.00 & 1 & 123.00 \\
Expansion valves & 77.00 & 2 & 154.00 \\
Solenoid valves & 120.00 & 4 & 480.00 \\
Timer & 40.00 & 1 & 40.00 \\
Head pressure control & 100.00 & 1 & 100.00 \\
Headmaster valve & 140.00 & 1 & 140.00 \\
Blower & 360.00 & 1 & 360.00 \\
Equipment initial Costs & & & $3,516.00$ \\
Electrical wiring and controls & & & 140.64 \\
Equipment installation & & & $1,902.40$ \\
Equipment freight & & & 47.56 \\
Total equipment initial costs & & & $6,896.20$ \\
Engineering and design & & 482.73 \\
\hline Total capital costs & & $7,378.93$ \\
Capital costs/year & & 633.19 \\
\hline
\end{tabular}


Table 7.600 bu drying system operating costs (\$/year)

\begin{tabular}{ll}
\hline Fixed costs & \\
\hline Insurance & 25.49 \\
Subtotal & 25.49 \\
\hline Variable costs & \\
\hline Labor cost & 366.00 \\
Electricity & $1,890.00$ \\
Maintenance and repair & 163.65 \\
Subtotal & $2,419.65$ \\
\hline Total costs & $2,913.25$ \\
Drying cost/bu & 0.49 \\
\hline
\end{tabular}

Table 8.6000 bu drying system capital costs (\$)

\begin{tabular}{llll}
\hline Component & Price (\$/each) & Quantity & Total Cost (\$) \\
\hline Compressor & $5,200.00$ & 1 & $5,200.00$ \\
Evaporators & $1,000.00$ & 2 & $1,000.00$ \\
Accumulator & 123.00 & 1 & 123.00 \\
Receiver & 151.00 & 1 & 151.00 \\
Expansion valves & 97.00 & 2 & 97.00 \\
Solenoid valves & 234.00 & 4 & 234.00 \\
Timer & 40.00 & 1 & 40.00 \\
Head pressure control & 100.00 & 1 & 100.00 \\
Headmaster valve & 140.00 & 1 & 140.00 \\
Blower & $10,000.00$ & 1 & $2,600.00$ \\
Equipment Initial Costs & & & $11,484.00$ \\
Electrical wiring and controls & & & 755.36 \\
Equipment installation & & & $7,553.60$ \\
Equipment freight & & & 188.84 \\
Total equipment initial costs & & $27,381.80$ \\
Engineering and design & & $1,916.73$ \\
Total capital costs & & $29,298.53$ \\
Capital costs/year & & 2514.12 \\
\hline
\end{tabular}

Table 9.6000 bu drying system operating costs (\$/year)

\begin{tabular}{ll}
\hline Fixed costs & \\
\hline Insurance & 83.26 \\
Subtotal & 83.26 \\
\hline Variable costs & $1,464.00$ \\
\hline Labor cost & $7,560.00$ \\
Electricity & 356.35 \\
Maintenance and repair & $9,380.35$ \\
Subtotal & $10,992.53$ \\
\hline Total costs & 0.46 \\
\hline Drying cost/bu &
\end{tabular}




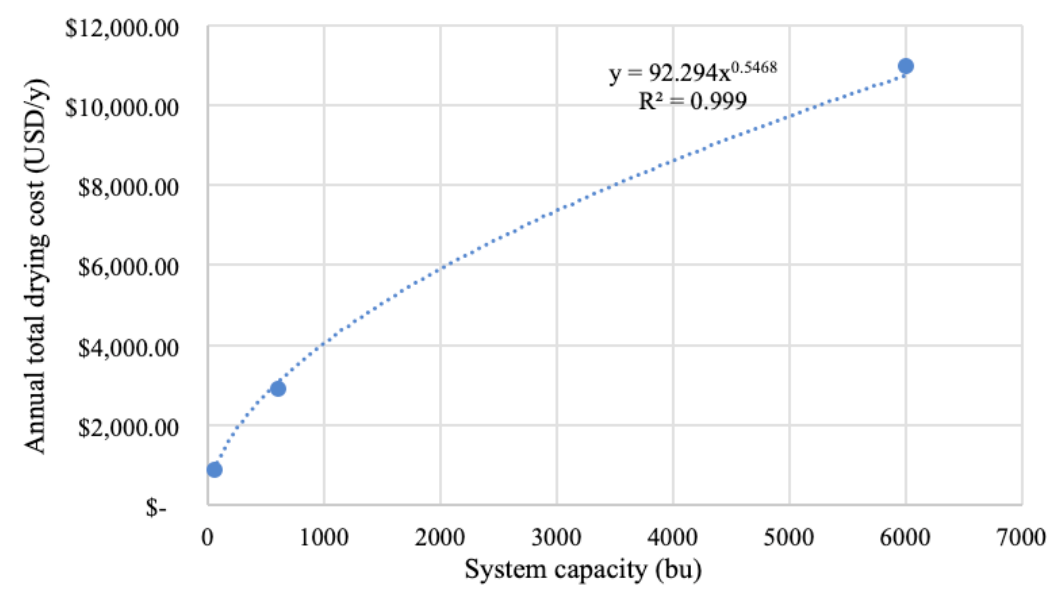

Figure 8. Annual total drying cost according to drying capacity

The drying cost for drying one bushel of corn was calculated by divided the annual drying cost by whole corn dried per year. The drying cost was reported as 0.62 USD per bushel, 0.49 USD per bushel, 0.46 USD per bushel for small (60 bu/batch), medium (600 bu/batch), large (6000 bu/batch) respectively. From Figure 9, it was clear to observe that the drying cost for drying one bushel of corn decreases while the drying capacity increases. The relationship among the three scales fit the power decrease well with the R-square value equal to 0.8913 The reason caused the R-square value difference was because the energy cost for one bushel of corn was similar for each scale due to the energy consumption for one bushel of corn was assumed as $3 \mathrm{~kW}-\mathrm{h}$, and the capital cost per bushel of corn dried was very close to medium and large scale.

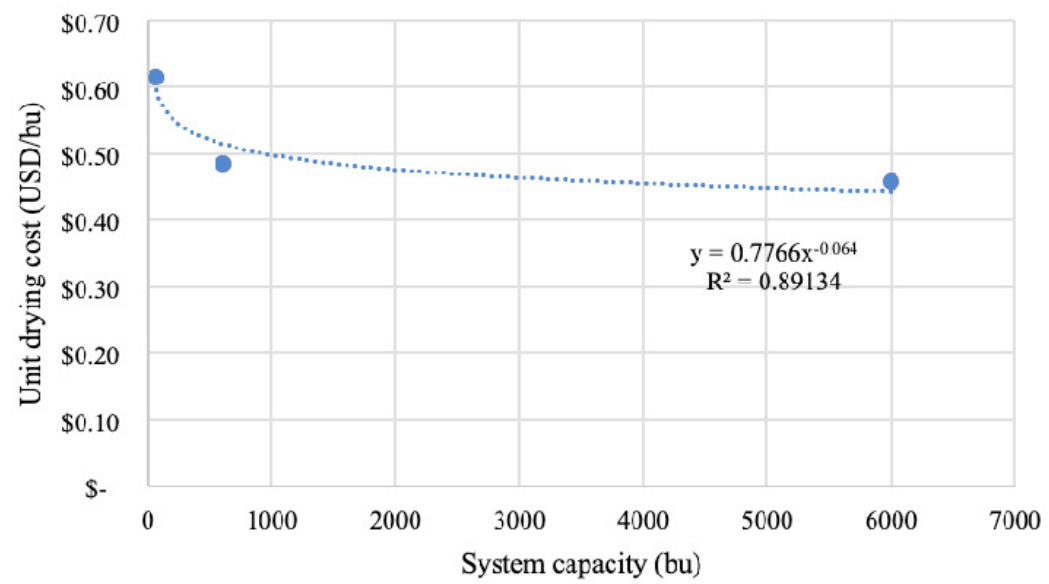

Figure 9. Unit drying cost according to drying capacity

To compare the drying cost for the present drying system with other drying systems, the beginning moisture of grain was set as $28 \%$, the ending moisture of grain was $15 \%$. The grain elevator drying cost was 0.0425 USD per point per bushel (West Central, 2016). If the corn was dried from $28 \%$ moisture content to $13 \%$ moisture content the drying cost for one bushel of corn was computed as 0.553 USD per bushel, which was lower than small scale drying cost and much higher than medium and large-scale drying system. The result indicates that the three scale of present drying system could save money compare to other drying systems under similar drying conditions.

\section{Conclusions}

Based on the TEA and LCA results, both total annual environmental impacts and the total annual cost was increased while the system scale expanded. Based on the LCA, the GHG emission for this low temperature drying system was higher than most of others off-farm and on-farm drying methods since the electricity used for drying grain was assumed to be come from the local coal plant. Although the GHG emission was very high 
under certain situation, the greenhouse gas emission could be improved by using cleaner electricity like wind power electricity or hydropower electricity. The unit cost of drying corn was decreased as the operation system scale expanded. The result indicated that the large scale system had lower operational cost compared with other on-farm drying methods; the medium scale and the large scale low temperature closed-cycle drying system was cheaper.

\section{References}

Beedie, M. (1995). Faxing new quality challenges: environment protection. Process Engineering, 76(10), s13-s14.

Bern, C. J. (1998). Preserving the Iowa corn crop: Energy use and $\mathrm{CO}_{2}$ release. Applied Engineering in Agriculture, 14(3), 293-299.

Brooker, D. B., Bakker-Arkema, F. W., \& Hall, C. W., (1992). Drying and storage of grains and oilseeds. Springer Science \& Business Media.

EIA (Energy Information Agency). (2016). Electric Power Monthly. Retrieved from https://www.eia.gov/ electricity/monthly

Gene, C. S., \& Olver, E. F. (1967). Temperature gradients in drying grain. Transactions of the ASAE, 10(2), 152-153.

Gunasekaran, S., \& Thompson, T. L. (1986). Optimal energy management in grain drying. Critical Reviews in Food Science \& Nutrition, 25(1), 1-48.

Hellevang, K. J., \& Reff, T. (1987). Calculating grain drying cost (AE-923). NDSU Extension Service, North Dakota State University.

Hunt, R. G., Franklin, W. E., \& Hunt, R. G. (1996). LCA—How it came about. The International Journal of Life Cycle Assessment, 1(1), 4-7.

Kenyon, D. E., \& Shove, G. C. (1969). Cyclic drying with hot and cold air (ASABE Paper No. 69333). St. Joseph, Mich.: ASABE.

Ma, M., \& Rosentrater, K. A. (2019). Assessment of a low temperature closed-cycle grain drying system. Journal of Food Research, 8(2), 1-10.

Morrison, D. W. (1979). Energy management in grain drying. Grain Drying and Energy Management Workshops, University of Illinois, Urbana. Champaign, Urbana, IL.

Peterson, W. H. (1979). Efficient crop drying. South Dakota Cooperative Extension Information, U.S. Department of Agriculture, South Dakota State University, Brookings, SD.

Plastina, A., \& Erwin, J. (2016). 2016 Iowa Farm Custom Rate Survey. Ag Decision Maker. Retrieved from https://blogs.extension.iastate.edu/agdm

Sadaka, S. (2014). Selection, performance and maintenance of grain bin fans. Cooperative Extension Service, University of Arkansas.

Shove, G. C. (1953). A laboratory investigation of the adaptability of the heat pump to batch drying of shelled corn (Unpublished MS thesis, Kansas State University, Manhattan).

Shove, G. C. (1970). Potential energy use in low-temperature grain conditioning. Transactions of the ASAE, 13(1), 58-60.

Spath, P. L., \& Mann, M. K. (2002). Environmental Aspects of Producing Electricity from a Coal-Fired Power Generation System-A Life Cycle Assessment. National Renewable Energy Laboratory, Golden, CO.

Spath, P. L., Mann, M. K., \& Kerr, D. R. (1999). Life cycle assessment of coal-fired power production. NREL Life Cycle Assessment. National Renewable Energy Laboratory, Golden, CO.

Stocker, T. F., Qin, D., Plattner, G. K., Tignor, M., Allen, S. K., Boschung, J., Midgley, B. M. (2013). IPCC, 2013: Climate change 2013: The physical science basis. Contribution of working group I to the fifth assessment report of the intergovernmental panel on climate change. Retrieved from https://www.ipcc.ch/ report/ar5/wg1

USDA-NASS. (2011). Usual planting and harvesting dates for US field crops. Retrieved from https://usda.library.cornell.edu

Warchalewski, J. R., Pradzynska, A., Gralik, J., \& Nawrot, J. (2000). The effect of gamma and microwave 
irradiation of wheat grain on development parameters of some stored grain pests. Molecular Nutrition \& Food Research, 44(6), 411-414.

\section{Copyrights}

Copyright for this article is retained by the author(s), with first publication rights granted to the journal.

This is an open-access article distributed under the terms and conditions of the Creative Commons Attribution license (http://creativecommons.org/licenses/by/4.0/). 